\title{
The Use of Soil Solarization for the Management of Soilborne Plant Pathogens in Strawberry and Red Raspberry Production
}

\author{
J. N. Pinkerton, USDA-ARS, HCRL, Corvallis, OR 97330; K. L. Ivors and P. W. Reeser, Department of Botany \\ and Plant Pathology, Oregon State University, Corvallis 97331; and P. R. Bristow and G. E. Windom, Washington \\ State University, Puyallup Research and Extension Center, Puyallup 98371
}

\begin{abstract}
Pinkerton, J. N., Ivors, K. L., Reeser, P. W., Bristow, P. R., and Windom, G. E. 2002. The use of soil solarization for the management of soilborne plant pathogens in strawberry and red raspberry production. Plant Dis. 86:645-651.

Root rot caused by Phytophthora fragariae var. fragariae and P. fragariae var. rubi are major concerns in strawberry and raspberry production in the Pacific Northwest. Of lesser importance is black root rot of strawberry, caused by a complex of fungi and nematodes. Soil solarization was evaluated in 1997 in a strawberry planting and in 1998 in a raspberry planting for: (i) enhancing plant health and growth, and (ii) reducing population densities of root-destroying pathogens. Plots were solarized from mid-July to mid-September. Maximum and mean soil temperatures in solarized plots recorded at $10 \mathrm{~cm}$ depth were 48 and $33^{\circ} \mathrm{C}$ in the strawberry plots and 46 and $29^{\circ} \mathrm{C}$ in the raspberry plots. These temperatures were 7 to $17^{\circ} \mathrm{C}$ higher than temperatures recorded in nonsolarized plots. Soil collected after solarization was assayed by growing bait plants, cv. Totem strawberry or cv. Qualicum raspberry, at $15^{\circ} \mathrm{C}$ for 6 weeks in saturated soil to promote infections. Root health and plant growth were evaluated after 6 weeks. Solarization significantly reduced $(P<0.05)$ root necrosis and increased root weight of bait plants compared to plants grown in soil from nonsolarized plots. Infection of strawberry roots by $P$. fragariae, Pythium, Rhizoctonia, and Cylindrocarpon spp. was reduced $(P<0.05)$ by solarization in sampled soil. Disease was reduced in cv. Hood strawberries and Qualicum and Skeena red raspberries planted in solarized field plots. In the second growing season, total number and number of healthy primocanes of Qualicum plants were greater $(P<0.05)$ in solarized plots compared to nonsolarized plots. Solarization combined with applications of mefenoxam was no more effective in controlling diseases than solarization alone, but better than mefenoxam alone. Skeena plants responded similarly, but the differences were not significant. Red raspberry plants growing in solarized soil yielded more fruit than plants growing in nonsolarized soil in the third year after solarization. Solarization has potential as a component in an integrated pest management program of root diseases in raspberry and strawberry production, particularly within the first 2 years following planting.
\end{abstract}

Additional keywords: black root rot, disease management, Fragariae, mefenoxam, methyl bromide alternatives, red stele, Ridomil Gold, Rubus idae

Soilborne pathogens are a major concern to red raspberry and strawberry producers throughout the Pacific Northwest. Red stele, caused by Phytophthora fragariae var. fragariae Hickman, and raspberry root rot, caused by $P$. fragariae var. rubi, can cause serious economic losses in cool, wet production areas $(12,16,31,47)$. Black root rot, caused by a complex of fungi and

Corresponding author: J. N. Pinkerton

E-mail: pinkertj@bcc.orst.edu

The research was funded in part by USDA Northwest Center for Small Fruit Research. Raspberry plants were provided gratis by Sakuma Bros. Farms Inc., Burlington, WA.

Accepted for publication 29 January 2002.

Publication no. D-2002-0325-02R

This article is in the public domain and not copyrightable. It may be freely reprinted with customary crediting of the source. The American Phytopathological Society, 2002. nematodes $(14,31)$, causes economic loss to the region's strawberry industry (29) and is prevalent in strawberry production worldwide (48). These pathogens reduce plant vigor, decrease yields, and can cause large areas in fields to "die out" in one or two seasons. Management of these diseases is difficult because the different pathogens involved require distinct chemical and cultural inputs for control.

Soil fumigation is widely used in small fruit production, but in the Pacific Northwest, growers are reluctant to fumigate due to high initial cost. Fumigation with methyl bromide-chloropicrin eradicates many of the fungi involved in the black root rot complex $(49,50)$, but reinvasion by fast growing fungi such as Pythium or Rhizoctonia may lessen the effectiveness of fumigation later in the growing season (27). Johnson et al. (24) determined that fumigation only delayed the onset of root rot in red raspberry plantings by 3 to 4 years. $P$. fragariae may persist in raspberry and strawberry fields for many years, limiting the efficacy of crop rotations for disease control. In addition, isolates of $P$. fragariae that are resistant to metalaxyl (Ridomil, Ciba, Greensboro, NC) have been found in strawberry plantings (38). Disease control is markedly reduced in some Washington fields when raspberries are replanted in soil with a history of metalaxyl use (P. Bristow, unpublished data). Several races of $P$. fragariae var. fragariae have been identified (31). With physiological races of the fungus found in different fields, it becomes difficult to maintain resistance. In addition, due to concerns about methyl bromide's role in ozone depletion, its manufacture and use in the United States will be banned in 2005 (11). These limitations leave the raspberry and strawberry industries searching for alternative management tools.

Soil solarization is a process that employs solar radiation to heat soil under a transparent plastic film to temperatures that are detrimental to soilborne pathogens. Increased soil temperatures can decrease populations of weeds and plant pathogens, including fungi, bacteria, and nematodes and control a variety of plant diseases $(13,27)$. Solarization targets mesophylic organisms, which include most plant pathogens and pests, without destroying thermotolerant fungi and Bacillus spp. (40). Reports of solarization controlling Fusarium oxysporum f. sp. vasinfectum for a period of over 3 years (28) and eliminating Verticillium dahliae to a depth of 120 $\mathrm{cm}$ (1) indicate that the mechanism of control is not solely through achieving lethal temperatures. Greenberger et al. (20) demonstrated that solarized soils are often more suppressive to certain soilborne pathogens than nonsolarized soils. Changes in the microflora following solarization may account for enhanced plant growth and induced suppressiveness to plant pathogens. Trichoderma spp. are among the microorganisms that survive the solar heating process $(6,13)$. Trichoderma spp. have been shown to parasitize mycelia of many fungal pathogens including Rhizoctonia and Sclerotium, inhibit the growth of Pythium, Phytophthora, Fusarium, and Heterobasidion spp., and reduce the diseases caused by most of these pathogens $(2,21)$. Solarization can enhance the effectiveness of other pest management approaches $(5,27,37)$ and has the additional 
advantages of being a nonchemical alternative method for pathogen control.

In Oregon, solarization has shown promise for the control of soilborne plant pathogenic fungi, bacteria, nematodes, and weeds $(33,36)$. In one study (33), introduced populations of Verticillium dahliae, Pratylenchus penetrans, and Agrobacterium tumefaciens were significantly reduced in the solarized plots, and P. cinnamomi was not recovered from the test soils following solarization. However, it is not known whether solarization in the Pacific Northwest will reduce plant damage and enhance plant health, if effects will persist for multiple years, or if solarization will be an economically viable management technique in raspberry and strawberry production. The objective of this research was to evaluate the use of soil solarization for reducing populations of root-destroying pathogens of strawberry and raspberry, thus enhancing plant health and growth in commercial production.

\section{MATERIALS AND METHODS}

Plot establishment. Experiments were established in a strawberry field and a raspberry field with histories of root disease. In 1997, the strawberry trial was established on Quatama loam at the North Willamette Research and Extension Center (NWREC) in Aurora, OR. Strawberries (cv. Totem) planted in the field in 1995 were of low vigor, and plant samples were diagnosed with red stele and the black root rot complex. The red raspberry trial was established at the Washington State University-Vancouver Research and Extension Unit (WSU-VREU) in Vancouver in 1998. The Hillsboro silt loam soil was naturally infested with $P$. fragariae var. rubi (12) and has been used for numerous field trials (8). These infested plots represented a unique opportunity to evaluate solarization for the management of natural populations of soilborne pathogens of both berry crops over a 2-year growing period.

Experimental design. The experimental design for the strawberry trial was a split plot design with 10 replications. Each treatment plot was $3 \times 3.8 \mathrm{~m}$. In late-July 1997 , the plots were rototilled to incorporate the previous strawberry crop and then irrigated to field capacity. A 0.6-mil transparent polyethylene film (Ginegar Plastic Products Ltd. 30053, Israel) was stretched across the soil surface of all solarized plots and secured in place by burying the edges. The other plot in each replication was left fallow as a nonsolarized control. The plots were solarized from 24 July to 23 September. During this solarization period, the nonsolarized plots were maintained weedfree by hand weeding and application of glyphosate (Roundup, Monsanto, St. Louis, MO). At the end of the solarization period, the tarps were removed and the plots were left fallow over the winter. To determine the effect of solarization on the health of the subsequent crop, five rows of bare root strawberry crowns (cv. Hood) were planted in each plot on 30 April 1998. Plants were spaced $30 \mathrm{~cm}$ apart within rows that were spaced $60 \mathrm{~cm}$ apart. The plants were grown according to recommended production practices (39).

The experimental design for the red raspberry trial was a randomized complete block design with six blocks. Treatments consisted of solarized and nonsolarized plots, each with and without application of the fungicide mefenoxam (Ridomil Gold, Ciba, Greensboro, NC). Individual plots consisted of $8.8 \mathrm{~m}$ of row. The east-west oriented rows were $3 \mathrm{~m}$ apart and a $1.8 \mathrm{~m}$ space was left between plots within rows. In July 1998, the experimental area was plowed and rototilled to bury plant residue, then irrigated to field capacity. A 0.6-mil transparent polyethylene film was stretched across the soil surface of plots to be solarized and secured in place by burying the edges. The remaining plots in each replication were left fallow as nonsolarized controls. Plots were solarized from 23 July to 23 September. On 23 September, the tarps were removed and the plots were left fallow over the winter. Shallow trenches were dug around solarized plots so that surface water from rain would flow around rather than through them. In October 1998, companion grass was planted as a cover crop between rows and between plots within rows to further minimize the movement of infested soil into solarized plots. In April 1999, the soil in all plots was worked to a depth of 7.5 to $10 \mathrm{~cm} \mathrm{(3}$ to 4 in.) with a garden rototiller. Solarized plots were rototilled before nonsolarized plots and care was taken not to move nonsolarized soil into solarized plots. Tissue culture-propagated plants of two root-rot susceptible cultivars were planted: Qualicum on 22 April and Skeena on 21 May. Five plants of each cultivar were planted per plot. Skeena plants were small so they were allowed to grow an additional month in the greenhouse before being planted in the field.

Mefenoxam was applied to the surface of the soil in the raspberry plots in a $0.9-\mathrm{m}$ wide band centered on the plant row (118.3 $\mathrm{ml}$ mefenoxam in 3,785 liter of water per $304.8 \mathrm{~m}$ of row). The fungicide was applied immediately prior to rain so the chemical was washed into the soil. If rain did not occur within 2 days after application, the planting was irrigated with $1.7 \mathrm{~cm}$ of water. Mefenoxam was applied immediately after planting and each fall (October) and spring (March) thereafter.

Soil temperatures were recorded hourly in a solarized and a nonsolarized plot at depths of 10 and $20 \mathrm{~cm}$ for strawberry and 10 and $30 \mathrm{~cm}$ for red raspberry during the period of solarization. Thermocouples, placed at these stated depths, were connected to a datalogger (Campbell Scientific, Logan, UT).
Sampling. For the strawberry trial, soil samples were collected in July (before solarization), September (after solarization), and in March 1998 (before planting). Each plot was divided into a grid consisting of 18 subplots $0.6 \times 1 \mathrm{~m}$ each. Samples consisted of 10 cores $(2.5 \times 30 \mathrm{~cm})$ collected from five subplots chosen randomly within each plot. For the red raspberry trial, 20 cores per plot were collected in July (before solarization) and September (after solarization). Soil samples were held at $5^{\circ} \mathrm{C}$ until bioassayed for the pathogens under controlled conditions in growth chambers.

On 14 July 1999, strawberry plants in five randomly chosen subplots within each plot were rated for vigor on a subjective scale of 1 to 4 : 1 = vigorous plants with numerous runners, $2=$ moderately vigorous plants, $3=$ stunted plants with a few runners, and $4=$ very stunted plants without runners. Single plants were dug carefully from each of these subplots. The roots of these plants were rated for severity of root disease according to the protocol used for plant bioassays.

In November 1999, red raspberry plants were cut off just above the soil and the fresh weight of the tops recorded. Data on the number of healthy and wilted primocanes were collected in July and September 2000 and height of healthy primocanes was measured in November 2000. The density of primocanes in the plant row and in the alleyways was determined on 8 June 2000. Healthy primocanes in fall 2000 were tied to a trellis and harvested for yield in 2001. All ripe berries were harvested by hand and weighed twice weekly from 22 June through 24 July.

Plant bioassay. The plant bioassay was based on methods described by Duncan (15) for baiting P. fragariae from soil. Rooted runners of strawberry Totem were used as indicator bait plants. Root initials were surface disinfested with $0.5 \% \mathrm{NaOCl}$ and rinsed in tap water for several minutes. The runners were rooted in individual cells of moist vermiculite. When the roots were 2 to $4 \mathrm{~cm}$ long, runners were detached from mother plants and planted in the soil samples. Soil samples were removed from cold storage and each sample was mixed evenly and placed in sterilized $5 \times 18 \mathrm{~cm}$ D-16 Deepot Cone-tainers (Stuewe and Sons, Corvallis, OR). A single rooted strawberry runner was transplanted into each soil sample. Control plants were planted in pasteurized field soil. The containers were spaced evenly apart to prevent cross contamination, and placed in a growth chamber (Percival, Boone, IA) set at $15^{\circ} \mathrm{C}$ with a $12 \mathrm{~h}$ photoperiod. To promote root infection, the lower $8 \mathrm{~cm}(18 \mathrm{~cm}$ long containers) of each container was submerged in a water-filled styrofoam cup with the water level being brought back to the top of the cup daily. After 6 weeks, plants were harvested by removing all soil 
from the roots, and the roots were evaluated visually for severity of root disease. Typical symptoms of strawberry root disease ranged from red to brown watersoaked regions to definite brick-red to brown to black lesions. These lesions were more apparent on the larger primary adventitious roots but were also found in great numbers on the finer secondary rootlets. The root rating scale ranged from a value of 0 to 5 , with a rating of 0 indicating no visible symptoms and a rating of 5 indicating complete death of the plant and root system. Pieces of symptomatic roots were plated on selective media (listed below) to ascertain the organisms associated with the lesions, while other pieces were examined for oospores. To determine the effects of treatment on plant growth, roots and shoots of each plant were oven dried at $70^{\circ} \mathrm{C}$ and weighed.

For red raspberry, the 48 soil samples were removed from cold storage, well mixed, and $250 \mathrm{~cm}^{3}$ placed in sterilized D16 Deepot Cone-tainers (Stuewe and Sons). Each container was planted with one tissue culture-propagated Qualicum plant. Containers were set in water-filled styrofoam cups. Plants were grown in a plant growth room (EGC, Chagrin Falls, $\mathrm{OH})$ set at 12 to $13^{\circ} \mathrm{C}$ with a $12 \mathrm{~h}$ photoperiod (fluorescent plus incandescent lamps). After 56 days, the roots were washed free of soil and the leaves and roots of each plant were rated separately for color and the roots were then oven dried $\left(100^{\circ} \mathrm{C}\right)$ and weighed. The leaf color rating scale ranged from 0 to $4 ; 0=$ necrotic (brown), 1 to $3=$ degrees of chlorosis, and $4=$ dark green. The root color rating scale ranged from 1 to $5 ; 1=$ white or a very light cream color and $5=$ mostly black or dark brown.

Isolation and identification of causal organisms. Strawberry roots from bioassay plants were sampled from 10 plants selected randomly from each treatment. When possible, adventitious roots with obvious infections and regions with distinct diseased-to-healthy transition zones were chosen over healthy roots. Generally, diseased areas were hard to find on plant roots grown in soil collected from solar- ized plots. Roots were prepared for isolation by removing adhering soil with a soft bristle brush in a shallow pan of water, rinsing thoroughly in cold tap water, surface-disinfesting for $2 \mathrm{~min}$ in $0.5 \% \mathrm{NaOCl}$, and finally rinsing three times in steriledeionized water. After blotting dry, 10 segments (approximately 5 to $10 \mathrm{~mm}$ ) were collected from these roots with the aid of a flamed scalpel working from the healthy to diseased gradient. Eight root segments were plated on two types of media (four segments per medium): 0.25strength PDA amended with 100 ppm streptomycin sulfate and 0.25 -strength PDA amended with 50 ppm metalaxyl and $100 \mathrm{ppm}$ streptomycin sulfate. Plates were incubated at $22^{\circ} \mathrm{C}$ in the dark for 4 weeks and were checked daily for fungal growth. All isolated fungi were subcultured on 0.50 -strength PDA and incubated at $22^{\circ} \mathrm{C}$. Isolated fungi were identified to genus using classical taxonomic procedures and growth characteristics on the media. The remaining two root segments collected were squash mounted on a microscope slide and inspected at $\times 100$ for characteristic oospores of $P$. fragariae var. fragariae (>22 $\mu \mathrm{m}$ diameter with amphigynous or paragynous antheridia).

\section{RESULTS}

Soil temperatures. In the strawberry trial at NWREC, the maximum soil temperatures reached $48^{\circ} \mathrm{C}$ at $10 \mathrm{~cm}$ and $36^{\circ} \mathrm{C}$ at $20 \mathrm{~cm}$ in the solarized plots compared to $31^{\circ} \mathrm{C}$ at 10 $\mathrm{cm}$ and $26^{\circ} \mathrm{C}$ at $20 \mathrm{~cm}$ in nonsolarized soils (Table 1). Mean daily soil temperatures in solarized plots averaged $33^{\circ} \mathrm{C}$ at $10 \mathrm{~cm}$ and $29^{\circ} \mathrm{C}$ at $20 \mathrm{~cm}$ through the season, compared to 23 and $21^{\circ} \mathrm{C}$, respectively, in nonsolarized plots (Table 1). At $10 \mathrm{~cm}$, temperatures were greater than 35 and $40^{\circ} \mathrm{C}$ for $594 \mathrm{~h}$ and 237 $\mathrm{h}$, respectively. Only $4 \mathrm{~h}$ were recorded with temperatures $>35^{\circ} \mathrm{C}$ in nonsolarized plots. Soil temperatures were lower in the raspberry plots at WSU-VREU compared to NWREC (Table 1). Mean and maximum temperatures recorded in solarized plots at $10 \mathrm{~cm}$ were 29 and $46^{\circ} \mathrm{C}$, respectively, and temperatures reached $35^{\circ} \mathrm{C}$ for only $225 \mathrm{~h}$. Maximum soil temperatures recorded at 30 $\mathrm{cm}$ were 27 and $32^{\circ} \mathrm{C}$ in nonsolarized and solarized plot, respectively.

Plant bioassay. Root disease ratings of strawberry plants grown in solarized soil were significantly lower $(P \leq 0.0001)$ compared to ratings of plants grown in soil collected before solarization and soil collected in nonsolarized plots in September (Table 2). However, root disease ratings of

Table 2. Effect of soil solarization on root disease and growth of strawberry ${ }^{\mathrm{x}}$

\begin{tabular}{llccc}
\hline & Treatment & Presolarization $^{\mathbf{y}}$ & Postsolarization $^{\mathbf{y}}$ & Preplanting $^{\mathbf{y}}$ \\
\hline Root disease & Solarized & $1.95 \mathrm{a}^{\mathrm{z}}$ & $0.17 \mathrm{~b}$ & $0.07 \mathrm{~b}$ \\
& Nonsolarized & $1.53 \mathrm{a}$ & $1.15 \mathrm{a}$ & $1.67 \mathrm{a}$ \\
\multirow{3}{*}{ Root weight (g) } & Control & $0.03 \mathrm{~b}$ & $0.01 \mathrm{~b}$ & $0.04 \mathrm{~b}$ \\
& Solarized & $0.70 \mathrm{a}$ & $1.50 \mathrm{~b}$ & $0.47 \mathrm{a}$ \\
& Nonsolarized & $0.79 \mathrm{a}$ & $0.88 \mathrm{a}$ & $0.54 \mathrm{a}$ \\
Shoot weight (g) & Control & $1.52 \mathrm{~b}$ & $1.55 \mathrm{~b}$ & $0.61 \mathrm{a}$ \\
& Solarized & $0.67 \mathrm{a}$ & $1.23 \mathrm{~b}$ & $0.63 \mathrm{a}$ \\
& Nonsolarized & $0.70 \mathrm{a}$ & $0.74 \mathrm{a}$ & $0.68 \mathrm{a}$ \\
& Control & $1.32 \mathrm{~b}$ & $1.27 \mathrm{~b}$ & $0.90 \mathrm{~b}$ \\
\hline
\end{tabular}

${ }^{\mathrm{x}}$ Root rot was assayed by growing 'Totem' strawberry plants in soil samples collected from the field plots. Plants were grown in saturated soil at $15^{\circ} \mathrm{C}$ for 6 weeks. Root disease was rated on a scale of 1 to 5 based on percentage of root length which was necrotic; $0=$ no disease, $0.25=5 \%$ disease, $0.5=10 \%, 1=20 \%, 2=40 \%, 4=>75 \%$, and $5=$ plant dead. Root and shoot weights were measured after drying overnight at $70^{\circ} \mathrm{C}$. Pasteurized field soil served as a control.

${ }^{\mathrm{y}}$ Soil was solarized from 24 July to 23 September 1997. Soil was collected from five randomly selected areas in each of the 10 solarized and nonsolarized plots on 17 July (presolariztion), on 23 September (immediately after solarization), and on 25 March.

${ }^{\mathrm{z}}$ Mean values within columns followed by different letters were significantly different $(P<0.01)$ according to the Waller-Duncan procedure.

Table 1. Soil temperatures in solarized and nonsolarized plots at North Willamette Research and Extension (NWREC) in Aurora, OR in 1997 and at Southwest Washington Research and Extension Center (SWREC) in Vancouver in 1998x

\begin{tabular}{|c|c|c|c|c|c|c|c|c|}
\hline \multirow[b]{2}{*}{ Location } & \multirow[b]{2}{*}{ Treatment } & \multirow[b]{2}{*}{ Depth $(\mathbf{c m})^{z}$} & \multicolumn{2}{|c|}{ Soil temperature ${ }^{\mathrm{y}}\left({ }^{\circ} \mathrm{C}\right)$} & \multicolumn{4}{|c|}{ Cummulative hours } \\
\hline & & & Mean & Maximum & $>30^{\circ} \mathrm{C}$ & $>35^{\circ} \mathrm{C}$ & $>40^{\circ} \mathrm{C}$ & $>45^{\circ} \mathrm{C}$ \\
\hline \multirow[t]{4}{*}{ NWREC } & Solarized & 10 & 33.2 & 48.1 & 999 & 594 & 237 & 58 \\
\hline & & 20 & 29.6 & 36.1 & 794 & 38 & 0 & 0 \\
\hline & Nonsolarized & 10 & 23.3 & 31.2 & 28 & 4 & 1 & 1 \\
\hline & & 20 & 21.5 & 25.9 & 5 & 4 & 0 & 0 \\
\hline \multirow[t]{4}{*}{ SWREC } & Solarized & 10 & 29.4 & 46.1 & 512 & 225 & 91 & 7 \\
\hline & & 30 & 28.1 & 32.2 & 221 & 0 & 0 & 0 \\
\hline & Nonsolarized & 10 & 22.3 & 31.2 & 12 & 0 & 0 & 0 \\
\hline & & 30 & 23.4 & 27.8 & 10 & 0 & 0 & 0 \\
\hline
\end{tabular}

$\bar{x}$ Temperatures were recorded hourly by a datalogger. Temperature data were collected from 24 July to 23 September at NWREC and 23 July to 23 September at SWREC.

y Mean daily temperature and highest temperature record for a single hour.

$\mathrm{z}$ Thermocouples were buried at each depth in one solarized and one nonsolarized plot at each location. 
plants grown in solarized and pasteurized soil were not significantly different. These effects still were evident in March 1999, 6 months after the solarization period. Differences also were observed in plant growth (Table 2). Dried root and shoot weights were significantly higher $(P<$ 0.0001 ) for plants grown in solarized (collected in September) and pasteurized soils compared to plants grown in nonsolarized soils (Table 2).

To determine the effects of solarization on red raspberry plant growth, both roots and leaves were evaluated. There were fewer chlorotic and necrotic leaves on plants grown in solarized soil compared to soil collected before solarization and soil collected from nonsolarized plots in late September, 1998 (Table 3). Similarly, roots of plants in solarized soil were lighter in color and weighed $20 \%$ more than those grown in nonsolarized soil. Roots of plants grown in solarized soil collected in September weighed significantly more $(47 \%)$ than roots of plants grown in soil collected in July before solarization.

Isolation and identification of causal organisms. Five fungal genera were consistently isolated from infected strawberry roots of bioassay plants: Pythium, binucleate and multinucleate Rhizoctonia, Fusarium, Cylindrocarpon, and unidentified dark, sterile, septate fungi (DSS). Oospores of $P$. fragariae var. fragariae also were observed in infected strawberry roots. No fungi were isolated from and no oospores were observed in roots of strawberry plants grown in control pasteurized field soil. The isolation frequencies of Pythium, Rhizoctonia, and Cylindrocarpon spp. from bioassay plants were significantly reduced by solarization $(P>0.03)$ (Table 4$)$. The incidence of $P$. fragariae var. fragariae oospores also was reduced by solarization $(P$ $=0.0005$ ). However, the isolation frequencies of Fusarium spp. and the DSS fungus were not significantly reduced by solarization. The isolation frequencies and incidence of all six fungi in nonsolarized plots did not change significantly after the solarization period $(P>0.4161)$ (Table 4$)$. In the nonsolarized plots immediately following the solarization period; the most commonly isolated fungi were $P$. fragariae var. fragariae (identified in $100 \%$ of the plots), and Pythium spp. (82\%), followed by Rhizoctonia spp. and DSS (both 45\%), and Cylindrocarpon and Fusarium spp. (both $27 \%$ ). In the solarized plots immediately following solarization, $P$. fragariae var. fragariae was identified in $20 \%$ of the plots, the DSS fungi were the most commonly isolated (30\%), followed by Fusarium spp. (20\%), and Rhizoctonia spp. (10\%). Pythium and Cylindrocarpon spp. were not isolated from any solarized plot on sample date 2 .

Field plant analyses. The growth of strawberry plants in the field plots was poor due to the late planting date and com-

Table 3. Growth and health of Qualicum red raspberry plants assayed in soil collected from plots before and after solarization ${ }^{\mathrm{w}}$

\begin{tabular}{lccc}
\hline Time & Leaf rating $^{\mathbf{x}}$ & Root rating $^{\mathbf{y}}$ & Root dry wt (g) $^{\text {Pretreatment nonsolarized }}$ \\
\hline Presttreatment nonsolarized & $1.1 \mathrm{a}^{\mathrm{z}}$ & $2.4 \mathrm{a}$ & $0.47 \mathrm{a}$ \\
Solarized & $1.1 \mathrm{a}$ & $2.1 \mathrm{a}$ & $0.55 \mathrm{~b}$ \\
\hline
\end{tabular}

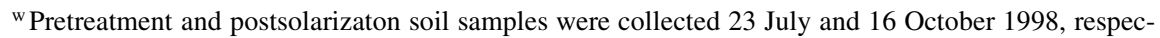
tively. Soil samples were stored at $5^{\circ} \mathrm{C}$ until assayed. Bioassay was conducted in a plant growth room maintained at $15^{\circ} \mathrm{C}$. Duration of bioassay was 56 days; from 22-23 Dec 1998 through $15 \mathrm{Feb}$ 1999 when the plants were evaluated.

${ }^{\mathrm{x}}$ Leaf color rating on a 0 to 4 scale; $0=$ necrotic (brown), 1 to $3=$ degrees of chlorosis, and $4=$ dark green.

${ }^{\mathrm{y}}$ Root color rating on a 1 to 5 scale; $1=$ white or a very light cream color and $5=$ mostly black or dark brown.

${ }^{\mathrm{z}}$ Mean values within columns followed by different letters were significantly different $(P<0.01)$ according to the Waller-Duncan procedure. petition from weeds. Plant vigor was not significantly different between solarized and nonsolarized plots. However, root disease severity ratings were lower $(P<$ $0.01)$ in solarized, (1.8) compared to nonsolarized plots (3.3).

At the end of the 1999 growing season there were noticeable differences in plant growth in the raspberry plots. On 5 November 1999, all canes were cut off just above the soil line and fresh weight taken on a per plant basis (Table 5). Top growth of Qualicum plants treated with mefenoxam was four to five times that of untreated plants. Increases in top growth due to solarization were not significant. Skeena plants were considerably smaller than Qualicum plants owing to the 1 month delay in planting. While none of the treatments significantly increased the top growth of Skeena, the trends were the same as for Qualicum with the most top growth in plots treated with mefenoxam.

When growth resumed in spring 2000, primocanes in solarized plots emerged about 1 week earlier than those in nonsolarized plots. There were also more primocanes growing in solarized plots and they were more vigorous. The first above ground symptom of root rot (primocane wilting) was not observed until early June. On 8 June 2000, primocanes in a $60-\mathrm{cm}$ wide band centered on the row (within the row) were counted as were primocanes on either side of the band (in the alleyway) (Table 6). For Qualicum, there were significantly more primocanes within the row and in the alleyway of solarized plots, indicating a more expansive root system. The trends were the same for Skeena but differences were not significant. Primocanes in the alleyways were removed after they were counted. The number of primocanes that wilted increased as the summer progressed, especially in nonsolarized plots. On 26 July and again on 13 September the number of healthy and diseased primocanes were counted (Table 7). In nonsolarized plots, nearly all of the primocanes that were going to emerge were present on 26 July and the incidence of wilted primocanes in these plots did not increase after that date. In contrast, in solarized

Table 4. Isolation frequency or incidence of fungi from roots of strawberry bioassay plants grown in soil collected from plots in July before solarization and September immediately following solarization

\begin{tabular}{|c|c|c|c|c|c|c|c|}
\hline \multirow[b]{2}{*}{ Treatment ${ }^{y}$} & & \multicolumn{6}{|c|}{ Isolation frequency or incidence ${ }^{x}$} \\
\hline & & Pythium & Phytophthora & Rhizoctonia & Fusarium & DDS & Cylindocarpon \\
\hline \multirow{2}{*}{ Solarized } & July & $0.70 \mathrm{a}^{\mathrm{z}}$ & $0.90 \mathrm{a}$ & $0.60 \mathrm{a}$ & $0.20 \mathrm{a}$ & $0.50 \mathrm{a}$ & $0.40 \mathrm{a}$ \\
\hline & Sept. & $0.00 \mathrm{~b}$ & $0.20 \mathrm{~b}$ & $0.10 \mathrm{~b}$ & $0.20 \mathrm{a}$ & $0.30 \mathrm{a}$ & $0.00 \mathrm{~b}$ \\
\hline \multirow[t]{2}{*}{ Nonsolarized } & July & $0.82 \mathrm{a}$ & $1.00 \mathrm{a}$ & $0.55 \mathrm{a}$ & $0.27 \mathrm{a}$ & $0.64 \mathrm{a}$ & $0.27 \mathrm{a}$ \\
\hline & Sept. & $0.82 \mathrm{a}$ & $1.00 \mathrm{a}$ & $0.45 \mathrm{a}$ & $0.27 \mathrm{a}$ & $0.45 \mathrm{a}$ & $0.27 \mathrm{a}$ \\
\hline
\end{tabular}

${ }^{\mathrm{x}}$ Frequency based on isolation of fungi from eight adventitious root segments sampled from each of 10 Totem strawberries planted in soil samples collected from each treatment in the field plots. Fungal isolates were plated on 0.25 -strength potato dextrose agar and identified to genus. Incidence of Phytophthora was based on two root segments from each subplot squash mounted on a microscope slide and inspected at $\times 100$ for characteristic oospores of Phytophthora fragariae var. fragariae.

${ }^{y}$ Soil was solarized from 24 July to 23 September 1997. Soil was collected from five randomly selected areas in each of the 10 solarized and nonsolarized plots on 17 July (presolariztion) and 23 September (immediately after solarization).

${ }^{\mathrm{z}}$ Mean values within columns followed by different letters were significantly different $(P<0.05)$ according to the Waller-Duncan procedure. 
plots, new primocanes continued to emerge after 26 July. After that date, some of the largest (and oldest primocanes) wilted so disease incidence significantly increased between late-July and mid-September. All diseased primocanes were removed on 13 September. The height of healthy primocanes was measured on 9 November. For Qualicum, both mefenoxam and solarization increased cane height. For Skeena, only the combination of solarization plus mefenoxam increased the height of healthy primocanes (Table 8). Skeena produced more primocanes than Qualicum but the primocanes were of equal size. The total length of healthy primocanes per plot for both cultivars was greatest in plots solarized and treated with mefenoxam, followed by plots that were only solarized.

Yield of raspberries from solarized plots was significantly higher than that for untreated check plots for both cultivars (Table 9). These differences were observed 3 years after solarization. Plots receiving only mefenoxam out-yielded untreated check plots but the differences were not significant. Yield per plot was positively correlated with the number of live fruiting canes per plot (Qualicum, $r=0.947$ and Skeena, $r=0.882$ ).

\section{DISCUSSION}

The Pacific Northwest, because of its maritime climate (with maximum daily temperatures of 25 to $40^{\circ} \mathrm{C}$ and little cloud cover during the summer) should be amenable to solarization. Temperatures achieved in solarized soil in this study were comparable to temperatures reported to be effective for controlling soilborne pathogens in California (25), Israel $(18,19)$, Florida (12), South Africa (3), and Australia (26). Although there are no data on the thermal sensitivity of $P$. fragrariae, the effects of elevated temperature and solarization on other cool climate-adapted Phytophthora spp. are well-documented

Table 5. Effect of solarization and applications of mefenoxam on primocane growth of two red raspberry varieties 6 months after planting in soil naturally infested with Phytophthora fragariae var. rubi

\begin{tabular}{|c|c|c|}
\hline \multirow[b]{2}{*}{ Treatment $^{y}$} & \multicolumn{2}{|c|}{$\begin{array}{c}\text { Grams fresh } \\
\text { weight per plant }\end{array}$} \\
\hline & Qualicum & Skeena \\
\hline Control & $76.1 \mathrm{a}^{\mathrm{z}}$ & $18.1 \mathrm{a}$ \\
\hline Solarized & 147.9 a & $30.8 \mathrm{ab}$ \\
\hline Mefenoxam & $275.0 \mathrm{~b}$ & $40.1 \mathrm{ab}$ \\
\hline Solarized + mefenoxam & $350.9 \mathrm{~b}$ & $46.7 \mathrm{~b}$ \\
\hline
\end{tabular}

$x$ Plants were cut to the ground on 5 November 1998 and total weight of cane from each plant was recorded.

y Mefenoxam (Ridomil Gold) was applied to the surface of the soil in a $0.9-\mathrm{m}$-wide band centered on the plant row.

${ }^{\mathrm{z}}$ Mean values within columns followed by different letters were significantly different $(P$ $<0.05$ ) according to the Waller-Duncan procedure.
$(3,20,26,32,46)$. Previous studies report that hyphal growth of $P$. cinnamomi was reduced $30 \%$ at $30^{\circ} \mathrm{C}(23)$, and at $36^{\circ} \mathrm{C}$ hyphae ceased to grow (51) and lysed (30). Clamydospores of $P$. cinnamomi were inactivated at $38^{\circ} \mathrm{C}$ after $30 \mathrm{~min}$, and the fungus was completely inactivated at 44 to $45^{\circ} \mathrm{C}$ in less than $20 \mathrm{~min}(4,25)$. Similarly, Pythium ultimum was reported not to survive at $46^{\circ} \mathrm{C}$ for $20 \mathrm{~min}$ in vitro (34) and to be controlled with solarization $(7,35,41)$. Rhizoctonia solani was reported to be injured at $45^{\circ} \mathrm{C}$ (37), but difficult to control with solarization (7). Also, Fusarium spp. have been reported to be more difficult to control with solarization than oomycetes $(6,7,9)$.

Our research indicates that soil solarization for 2 months significantly reduced strawberry root necrosis and root infection by P. fragariae, Pythium, Rhizoctonia, and Cylindrocarpon spp. In addition, disease incidence and severity in raspberry and strawberry plants grown in solarized field plots were less than in nonsolarized plots. However, solarization did not eliminate the fungal pathogens involved in red stele or the black root rot complex. Mortality rates are associated with the heat sensitivity of the organisms and with the predominant environmental conditions at certain mois- ture levels, temperatures, and exposure times $(27,34)$. Soil temperatures at $10 \mathrm{~cm}$ depth in solarized plots exceeded $35^{\circ} \mathrm{C}$ for $594 \mathrm{~h}$ and $225 \mathrm{~h}$ at NWREC and WSUVREC, respectively, while soil temperatures recorded at $30 \mathrm{~cm}$ at WSU-VREC exceeded $30^{\circ} \mathrm{C}$ for $221 \mathrm{~h}$, but did not reach $35^{\circ} \mathrm{C}$. However, sub-lethal temperatures can weaken propagules and reduce germination and infection of soilborne plant pathogens $(17,43)$. The efficacy of these thermal doses was confirmed by the lower recovery of $P$. fragariae and Pythium spp. in bait plant assays. Rhizoctonia spp. were reduced by solarization but were not completely eliminated, while the isolation frequency of Fusarium spp. from strawberry roots remained unchanged. We believe that the recovery of $P$. fragariae, Rhizoctonia spp., Fusarium spp., and DSS fungi from solarized plots may have been partially a sampling artifact, since these fungi were recovered only from subplots on the outside perimeter of the solarized area where soil temperature may have been lower.

Because strawberry and raspberry plantings in the Pacific Northwest may remain in production 4 to 20 years, preplant treatments, such as soil fumigation, which can provide multiple year suppression of plant diseases and pests are needed. We observed

Table 6. Effect of solarization and mefenoxam on the density of primocanes of red raspberry in the plant row and in the alleyway 13 months after planting

\begin{tabular}{lccccc}
\hline & \multicolumn{3}{c}{ Number of primocanes per plots } \\
\cline { 2 - 3 } \cline { 5 - 6 } \cline { 5 - 6 } Treatment & \multicolumn{2}{c}{ Qualicum } & & \multicolumn{2}{c}{ Skeena } \\
\cline { 2 - 3 } \cline { 5 - 6 } Control & $14.0 \mathrm{a}^{\mathrm{z}}$ & $2.8 \mathrm{a}$ & & $25.0 \mathrm{a}$ & $0.7 \mathrm{a}$ \\
Mefenoxam & $36.7 \mathrm{c}$ & $3.8 \mathrm{a}$ & & $36.0 \mathrm{a}$ & $2.7 \mathrm{a}$ \\
Solarized & $55.0 \mathrm{c}$ & $22.0 \mathrm{~b}$ & & $52.8 \mathrm{a}$ & $6.7 \mathrm{a}$ \\
Solarized + mefenoxam & $67.7 \mathrm{c}$ & $16.0 \mathrm{~b}$ & & $60.7 \mathrm{a}$ & $8.8 \mathrm{a}$ \\
\hline
\end{tabular}

$\mathrm{x} 60$-cm-wide band center on the plant row.

$\mathbf{y}$ From edge of band to center of alleyway on either side of the plant row.

${ }^{\mathbf{z}}$ Mean values within columns followed by different letters were significantly different $(P<0.05)$ according to the Waller-Duncan procedure.

Table 7. Effect of solarization and applications of mefenoxam on primocane growth of two red raspberry varieties in soil infested with Phytophthora fragariae var. rubi during the second year after planting

\begin{tabular}{|c|c|c|c|c|}
\hline \multirow[b]{2}{*}{ Treatment } & \multicolumn{2}{|c|}{26 July 2000} & \multicolumn{2}{|c|}{13 September 2000} \\
\hline & Qualicum & Skeena & Qualicum & Skeena \\
\hline \multicolumn{5}{|c|}{ Total number of primocanes per plot } \\
\hline Control & $10.2 \mathrm{a}^{\mathrm{z}}$ & $19.2 \mathrm{a}$ & $8.5 \mathrm{a}$ & $22.7 \mathrm{a}$ \\
\hline Mefenoxam & $25.3 \mathrm{a}$ & $35.3 \mathrm{a}$ & $27.8 \mathrm{a}$ & $43.3 \mathrm{a}$ \\
\hline Solarization & $53.8 \mathrm{~b}$ & $47.0 \mathrm{ab}$ & $61.3 \mathrm{~b}$ & $61.3 \mathrm{a}$ \\
\hline Solarization + mefenoxam & $59.5 \mathrm{~b}$ & $60.3 \mathrm{~b}$ & $74.3 \mathrm{~b}$ & $79.0 \mathrm{a}$ \\
\hline \multicolumn{5}{|c|}{ Number healthy primocanes per plot } \\
\hline Control & $7.5 \mathrm{a}$ & $16.5 \mathrm{a}$ & $6.3 \mathrm{a}$ & $16.3 \mathrm{a}$ \\
\hline Mefenoxam & $18.5 \mathrm{a}$ & $26.2 \mathrm{a}$ & $18.0 \mathrm{a}$ & $26.3 \mathrm{a}$ \\
\hline Solarized & $43.0 \mathrm{~b}$ & $44.2 \mathrm{ab}$ & $41.8 \mathrm{~b}$ & $53.5 \mathrm{ab}$ \\
\hline Solarized + mefenoxam & $47.5 \mathrm{~b}$ & $57.0 \mathrm{~b}$ & $47.2 \mathrm{~b}$ & $67.5 \mathrm{~b}$ \\
\hline \multicolumn{5}{|l|}{ Percent wilted } \\
\hline Control & $22.3 \mathrm{a}$ & $15.9 \mathrm{ab}$ & $18.9 \mathrm{a}$ & $14.1 \mathrm{a}$ \\
\hline Mefenoxam & $18.9 \mathrm{a}$ & $21.7 \mathrm{a}$ & $23.0 \mathrm{a}$ & $16.5 \mathrm{a}$ \\
\hline Solarized & $23.1 \mathrm{a}$ & $7.4 \mathrm{ab}$ & $35.2 \mathrm{a}$ & $31.5 \mathrm{a}$ \\
\hline Solarized + mefenoxam & $20.9 \mathrm{a}$ & $4.5 \mathrm{~b}$ & $38.3 \mathrm{a}$ & $32.6 \mathrm{a}$ \\
\hline
\end{tabular}

${ }^{\mathrm{z}}$ Mean values within columns followed by different letters were significantly different $(P<0.05)$ according to the Waller-Duncan procedure. 
Table 8. Effect of solarization and applications of mefenoxam on healthy primocane growth of two red raspberry varieties in soil naturally infested with Phytophthora fragariae var. rubi

\begin{tabular}{lccccc}
\hline & \multicolumn{2}{c}{ Mean height $(\mathbf{c m})^{\mathbf{y}}$} & & \multicolumn{2}{c}{ Total length per plot $(\mathbf{m})^{\mathbf{y}}$} \\
\cline { 2 - 3 } \cline { 5 - 6 } Treatment & Qualicum & Skeena & & Qualicum & Skeena \\
\hline Control & $47.6 \mathrm{a}^{\mathrm{z}}$ & $68.7 \mathrm{a}$ & & $3.54 \mathrm{a}$ & $12.79 \mathrm{a}$ \\
Mefenoxam & $78.5 \mathrm{~b}$ & $84.6 \mathrm{ab}$ & & $12.97 \mathrm{a}$ & $22.22 \mathrm{a}$ \\
Solarization & $107.4 \mathrm{~b}$ & $90.6 \mathrm{ab}$ & & $45.45 \mathrm{~b}$ & $51.48 \mathrm{~b}$ \\
Solarization + mefenoxam & $109.4 \mathrm{~b}$ & $111.5 \mathrm{~b}$ & & $54.74 \mathrm{~b}$ & $75.30 \mathrm{~b}$ \\
\hline
\end{tabular}

y Data were collected on 9 November 2000, 2 years after solarization.

${ }^{\mathrm{z}}$ Mean values within columns followed by different letters were significantly different $(P<0.05)$ according to the Waller-Duncan procedure.

Table 9. Effect of solarization and applications of mefenoxam on berry yield of two red raspberry varieties in soil infested with Phytophthora fragariae var. rubi

\begin{tabular}{lll}
\hline & \multicolumn{2}{c}{$\begin{array}{c}\text { Berry yield per } \\
\text { plot }(\mathbf{k g})^{\mathbf{y}}\end{array}$} \\
\cline { 2 - 3 } Treatment & Qualicum & Skeena \\
\hline Untreated check & $0.093 \mathrm{a}^{\mathrm{z}}$ & $0.917 \mathrm{a}$ \\
Mefenoxam & $1.146 \mathrm{ab}$ & $1.633 \mathrm{a}$ \\
Solarized & $2.721 \mathrm{~b}$ & $5.701 \mathrm{~b}$ \\
Solarized + mefenoxam & $2.383 \mathrm{~b}$ & $5.894 \mathrm{~b}$ \\
$P=$ & 0.035 & 0.018 \\
\hline
\end{tabular}

y Data were collected during June and July 2001, almost 3 years after solarization.

${ }^{2}$ Mean values within columns followed by different letters were significantly different $(P$ $<0.05)$ according to the Waller-Duncan procedure.

suppression of root rot in raspberry and strawberry plantings two or more years after solarization. The benefits of soil solarization could aid in the establishment of new plantings. Other research also has documented disease suppression for 1 to 3 years following solarization $(18,19,28,40,44)$. These long-term effects are not explained solely by thermal inactivation of pathogens, but involve other physical, chemical, and biological mechanisms. For example (32), Pinkas reported that hyphal growth and production of clamydospore of $P$. cinnamomi and infection were suppressed in soil following solarization. Induced suppression has been attributed to modification of the community structure of soil microflora following solarization. Selection apparently favors populations of heat tolerant bacteria, actinomycetes, and fungi that are antagonistic to soilborne plant pathogens $(13,19,20,33,40,41,44)$. Certain actinomycetes are antagonistic to $P$. fragariae var. rubi (45).

Soil solarization has been reported to be as effective as methyl bromide fumigation (22) and metalaxyl (46) for control of Phytophthora root diseases. Our results indicate that solar heating also has the potential for nonchemical management of soilborne diseases of raspberry and strawberry in cooler, northern regions. The prospect of combining solarization with fumigation (5), and cultural (37) and biological control $(41,42)$ makes solarization a complementary component of integrated pest management programs (10). Effective inte- grated programs for controlling Phytophthora root rot of raspberry have been developed based on hilling to improve soil drainage, applications of metalaxyl, amending soil with high rates of gypsum, and use of resistant cultivars $(8,47)$. However, as pest and pathogen populations develop resistance to pesticides or overcome host resistance, solarization may become a viable component in integrated management strategies. Solarization could be a particularly attractive application for small fruit production because the polyethylene tarp can be left on after solar heating (22), followed by planting through this plastic mulch for extended weed control and increased soil temperature for early season root development. Further investigations are needed to determine whether solarization is cost effective and has a role in the management of soilborne fungal diseases in strawberry and raspberry production.

\section{ACKNOWLEDGMENTS}

We would like to thank Tim Lair for technical assistance with aspects of this research and the WSU Master Gardeners-Clark County for harvesting the red raspberry trial.

\section{LITERATURE CITED}

1. Ashworth, L. J., Jr., and Gaona, S. A. 1982. Evaluation of clear polyethylene mulch for controlling Verticillium wilt in established pistachio nut groves. Phytopathology 72:243246.

2. Baker, K. F., and Cook, J. R. 1982. Biological Control of Plant Pathogens. The American Phytopathological Society, St. Paul, MN.

3. Barbercheck, M. E., and von Broembsen, S. L. 1986. Effects of soil solarization on plant parasitic nematodes and Phytophthora cinnamomi in South Africa. Plant Dis. 70:945-950.

4. Benson, D. M. 1978. Thermal inactivation of Phytophthora cinnamomi for control of Fraser Fir root rot. Phytopathology 68:1373-1376.

5. Ben-Yephet, Y., Melero-Vera, J. M., and DeVay, J. E. 1988. Interaction of soil solarization and metam-sodium in the destruction of Verticillium dahliae and Fusarium oxysporum f. sp. vasinfectum. Crop Prot. 7:327-331. J., and DeVay, J. E. 1987. Comparative effects of soil solarization with single and double layers of polyethylene film on survival of Fusarium oxysporum f. sp. vasinfectum. Phytoparasitica 15:181-185.

7. Bihan, B. L., Soulas, M. L., Camporota, P., Salerno, M. I., and Perrin, R. 1997. Evaluation of soil solar heating for control of damping-off fungi in two forest nurseries in France. Biol. Fertil. Soils 25:189-195.

8. Bristow, P. R., Daubany, H. A., Sjulin, T. M.,
6. Ben-Yephet, Y., Stapleton, J. J., Wakeman, R.
Pepin, H. S., Nesby, R., and Windom, G. E. 1988. Evaluation of Rubus germplasm for reaction to root rot caused by Phytophthora erythroseptica. J. Am. Soc. Hortic. Sci. 113:588-591.

9. Chellemi, D. O., Olson, S. M., and Mitchell, D. J. 1994. Effects of soil solarization and fumigation on survival of soilborne pathogens of tomato in northern Florida. Plant Dis. 78:1167-1172.

10. Chellemi, D. O., Olson, S. M., Mitchell, D. J., Secker, I., and McSorley, R. 1997. Adaptation of soil solarization to the integrated management of soilborne pests of tomato under humid conditions. Phytopathology 87:250-258.

11. Clean Air Act. 1990. Title VI. Stratospheric Ozone Protection. Pub L. 101-549, Section 6001. U.S. Congress, Washington, D.C.

12. Converse, R. H., and Schwartz, C. D. 1968. A root rot of red raspberry caused by Phytophthora erythroseptica. Phytopathology 58:56-59.

13. DeVay, J. E. 1991. Historical review and principles of soil solarization. Pages 1-15 in: Soil Solarization. J. E. DeVay, J. J. Stapleton, and C. L. Elmore, eds. FAO Plant Prot. Bull.

14. Drozdowski, J. 1987. A survey of fungi associated with strawberry black root rot in commercial fields. Adv. Strawberry Prod. 6:47-49.

15. Duncan, J. M. 1976. The use of bait plants to detect Phytophthora fragariae in soil. Trans. Br. Mycol. Soc. 66:85-89.

16. Duncan, J. M., and Kennedy, D. M. 1989. The effect of waterlogging on Phytophthora root rot of red raspberry. Plant Pathol. 38:161-168.

17. Freeman, S., and Katan, J. 1988. Weakening effect on propagules of Fusarium by sublethal heating. Phytopathology 78:1656-1661.

18. Freeman, S., Sztejnberg, A., Shabi, E., and Katan, J. 1990. Long-term effect of soil solarization for the control of Rosellinia necatrix in apple. Crop Prot. 9:312-316.

19. Gamliel, A., and Katan, J. 1993. Suppression of major and minor pathogens by fluorescent pseudomonads in solarized and nonsolarized soil. Phytopathology 83:68-75.

20. Greenberger, A., Yogev, A., and Katan, J. 1987. Induced suppressiveness in solarized soils. Phytopathology 77:1663-1667.

21. Harman, G. E. 2000. Myths and dogma of biocontrol: Changes in perceptions derived from research on Trichoderma harizianum $\mathrm{T}$ 22. Plant Dis. 84:377-393.

22. Hartz, T. K., DeVay, J. E., and Elmore, C. L. 1993. Solarization is an effective soil disinfestation technique for strawberry production Hortscience 28:104-106.

23. Hine, R. B., Alaban, C., and Klemmer, H. 1964. Influence of soil temperature on root and heart root of pineapple caused by $P h y-$ tophthora cinnamomi and Phytophthora parasitica. Phytopathology 54:1287-1289.

24. Johnson, F., Crandall, P. C. and Fisher, J. R. 1973. Soil fumigation and its effect on raspberry root rot. Plant Dis. Rep. 56:467-470.

25. Juarez-Palacios, C., Felix-Gastelum, R., Wakeman, R. J., Paplomatas, E. J., and DeVay, J. E. 1991. Thermal sensitivity of three species of Phytophthora and the effect of soil solarization on their survival. Plant Dis. 75:1160-1164.

26. Kassaby, F. Y. 1985. Solar-heating soil for control of damping-off diseases. Soil Biol. Biochem. 17:429-434.

27. Katan, J. 1981. Solar heating (solarization) of the soil for control of soilborne pests. Annu. Rev. Phytopathol. 19:211-236.

28. Katan, J., Fishler, G., and Grinstein, A. 1983. Short- and long-term effects of soil solarization and crop sequence on Fusarium wilt and yield of cotton in Israel. Phytopathology 73:1215-1219

29. Miller, P. W. 1948. Studies on the cause of 
strawberry root rot in Oregon. Plant Dis. Rep. 32:309-316.)

30. Nesbitt, H. J., Malajcuk, N. and Glenn, A. R. 1979. Effect of soil moisture and temperature on the survival of Phytophthora cinnamomi Rands in soil. Soil Biol. Biochem. 11:137140.

31. Paulus, A. O. 1990. Fungal diseases of strawberry. Hortscience 25:885-889.

32. Pinkas, Y., Kariv, A, and Katan, J. 1984. Soil solarization for the control of Phytophthora cinnamomi: Thermal and biological effects. Phytopathology 74:796.

33. Pinkerton, J. N., Ivors, K. L., Miller, M. L., and Moore, L. W. 2000. Effect of soil solarization and cover crops on populations of selected soilborne plant pathogens. Plant Dis. 84:952-960.

34. Pullman, G. S., DeVay, J. E., and Garber, R. H. 1981. Soil solarization and thermal death: Logarithmic relationship between time and temperature for four soilborne plant pathogens. Phytopathology 71:959-964.

35. Pullman, G. S., DeVay, J. E., Garber, R. H., and Weinhold, A. R. 1981. Soil solarization: Effects of Verticillium wilt of cotton and soilborne populations of Verticillium dahliae, Pythium spp., Rhizoctonia solani, and Thielaviopsis basicola. Phytopathology 71:954-959.

36. Raio, A., Zoina, A. and Moore, L. M. 1997. The effect of solar heating of soil on natural and inoculated agrobacteria. Plant Pathol. 46:320-328
37. Ramirez-Villapudua, R. J., and Munnecke, D. E. 1988. Effect of solar heating and soil amendments of cuciferous residues on Fusarium oxysporium $\mathrm{f}$. $\mathrm{sp}$. conglutinans and other organisms. Phytopathology 78:289-295.

38. Reeser, P. W., and Pscheidt, J. W. 1996. Insensitivity to metalaxyl in isolates of Phytophthora fragariae var. fragariae from strawberry in Oregon. (Abstr.) Phytopathology $86:$ S111.

39. Scheer, W. P. A., and Garren, R., 1981. Commercial Red Raspberry Production. Washington State University, Oregon State University, and University of Idaho, PNW Bull. 176, Washington State University, Pullman.

40. Stapleton J. J. and DeVay, J. E. 1982. Effect of soil solarization on populations of selected soilborne microorganisms and growth of deciduous fruit tree seedlings. Phytopathology 72:323-326.

41. Stapleton, J. J., and DeVay, J. E. 1984. Thermal components of soil solarization as related to exchange in soil and root microflora and increased plant growth response. Phytopathology 74:255-259.

42. Sztejnberg, A., Freeman, S., Chet, I., and Katan, J. 1987. Control of Rosellinia necatrix in soil and apple orchard by solarization and Trichoderma harzianum. Plant Dis. 71:365-369.

43. Tjamos, E. C., and Favel, D. R. 1995. Detrimental effects of sublethal heating and Talaromyces flavus on microsclerotia of Verticillium dahliae. Phytopathology 85:388-392.
44. Tjamos, E. C., and Paplomatas, E. J. 1988 Long-term effect of soil solarization in controlling Verticillium wilt of globe artichokes in Greece. Plant Pathol. 37:507-515.

45. Toussaint V., Valios, D., Dodier, M., Faucher, E., Déry, C., Brzezinski, R. Ruest, L., and Beaulieu, C. 1997. Characterization of actinomycetes antagonistic to Phytophthora fragariae var. rubi, the causal agent of raspberry root rot. Phytoprotection 78:43-51

46. Wicks, T. J. 1988. Effect of solarisation on the control of Phytophthora cambivora in almond and cherry. Aust. J. Exp. Agric. 28:539-545.

47. Wilcox, W. F., Prits, M. P., and Kelly, M. J. 1999. Integrated control of Phytophthora root rot of red raspberry. Plant Dis. 83:1149-1154.

48. Wing, K. B., Pritts, M. P., and Wilcox, W. F. 1994. Strawberry black root rot: A review. Adv. Strawberry Research 13:13-19.

49. Wolf, D., Hartman, J. R., Brown, G. R., and Strang, J. 1990. The influence of soil fumigation on strawberry yield and economics in black root rot infested fields. Appl. Agric. Res. 5:17-20.

50. Yuen, G. Y., Schroth, M. N., Weinhold, A. R., and Hancock, J. G. 1991. Effects of soil fumigation with methyl bromide and chloropicrin on root health and yield of strawberry. Plant Dis. 75:416-420.

51. Zentmeyer, G. A. 1980. Phytophthora cinnamomi and the Diseases It Causes. Monogr. 10 American Phytopathological Society, St. Paul, $\mathrm{MN}$. 